\title{
Artificial G-wire Switch with 2,2'-Bipyridine Units Responsive to Divalent Metal Ions
}

Daisuke Miyoshi, Hisae Karimata, Zhong-Ming Wang, Kazuya Koumoto,

\author{
and Naoki Sugimoto*
}

Frontier Institute for Biomolecular Engineering Research (FIBER), and Department of

Chemistry, Faculty of Science and Engineering, Konan University, 8-9-1 Okamoto,

Higashinada-ku, Kobe 658-8501, Japan 


\section{Synthetic procedures for the phosphoramidite of bipy unit and G1}

\section{General methods}

Thin layer chromatography (TLC) was performed on $0.25 \mathrm{~mm}$ Merck precoated silica plates $60 \mathrm{~F}_{254}$. The silica gel used for the column chromatography was Wakosil C-200 (wako Pure Chemical Industries. Ltd.). The ${ }^{1} \mathrm{H}-\mathrm{NMR}$ spectra were recorded at $300 \mathrm{MHz}$ using a Varian Unity-300 NMR spectrometer, with tetramethylsilane as the internal standard. Reversed-phase high performance liquid chromatography (RP HPLC) analysis and purification of the oligonucleotides was performed by a Tosoh HPLC system. Mass measurements of the oligonucleotides were done by a Voyager DE matrix-assisted laser desorption ionization time-of-flight (MALDI-TOF) mass spectrometer (Applied Biosystems). Two microliters of oligonucleotide matrix solution was spotted onto a golden sample plate, and all measurements were taken in the linear negative-ion mode. The fresh matrix solution, which was prepared by dissolving $25 \mathrm{mg}$ of 3-hydropicolinic acid and $4 \mathrm{mg}$ of ammonium citrate in $300 \mu \mathrm{l}$ of $50 \%$ acetonitrile, was used for every MS measurement.

All chemicals for the organic syntheses were purchased from the Wako Co. unless otherwise indicated. The common solvents and reagents for the DNA/RNA synthesizer (Applied Biosystems 391) were purchased from Glen Research Co., Ltd.. 

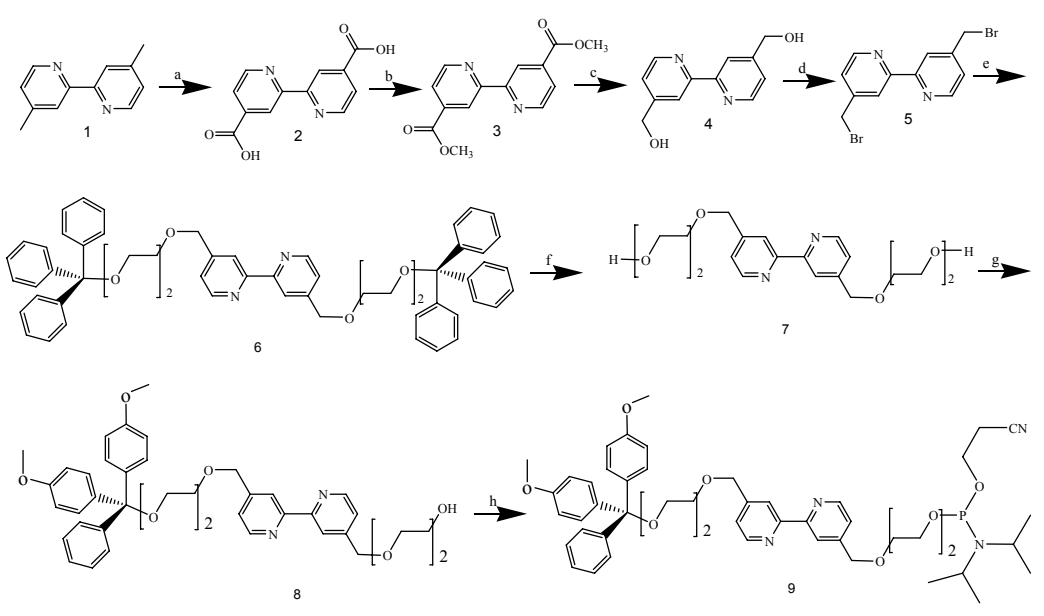

Scheme S1. The synthetic routine for phosphoramidite of 4,4'-dimethyl-2,2'-bipyridine. Reagents and conditions: (a)

$\mathrm{KMnO}_{4} / 25 \% \mathrm{H}_{2} \mathrm{SO}_{4}$, reflux $12 \mathrm{~h}, 50 \%, 8 \mathrm{~B} 9 \mathrm{H}_{2} \mathrm{SO}_{4} / \mathrm{CH}_{3} \mathrm{OH}$, reflux $24 \mathrm{~h}, 99 \%$, (c) $\mathrm{NaBH}_{4} /$ methanol, reflux 30h, 30\%, (d) $48 \% \mathrm{HBr}$, reflux 10h, 30\%, (e) 2-(2-Triphenylmethoxyethoxy)ethanol, $\mathrm{NaH} / \mathrm{THF}$, reflux, $48 \mathrm{~h}$ (f) $\mathrm{CF}_{3} \mathrm{COOH}$, room temperature, $1 \mathrm{~h}, 27 \% \quad(\mathrm{~g})$ 4,4-dimethoxytrityl chloride/pyridine, room temperature, $36 \mathrm{~h}, 20 \%$, 2-cyanoethyl-N,N,N',N'-tetraisopropyl-phosphrodiamidite/1H-tetrazole, room temperature, $3 \mathrm{~h}$.

2,2'-bipyridine-4,4'-dicarboxylic acid (2).

The cooled solution $\left(<5^{\circ} \mathrm{C}\right)$ of 4,4-dimethyl-2,2'-bipyridine $(10 \mathrm{~g}, 54 \mathrm{mmol})$ in $50 \%$ sulfuric acid $(180 \mathrm{~mL})$ was added into potassium permanganate $(20 \mathrm{~g}, 127 \mathrm{mmol})$. After stirring for $50 \mathrm{~min}$ the solution was allowed to warm to ambient temperature. Another portion of potassium permanganate $(20 \mathrm{~g}, 127 \mathrm{mmol})$ was added after the solution was chilled on ice. The reaction was refluxed overnight during which time the color changed from a dark purple to a milky white. The reaction mixture was added into water $(200 \mathrm{~mL})$. Much more precipitate could be obtained. After the reaction mixture was cooled and then was filtered through a Bush funnel and the white product was collected. Yield: $6.0 \mathrm{~g}(27 \mathrm{mmol}, 50 \%)$. This compound exhibited poor solubility 
characteristics in water, but ${ }^{1} \mathrm{H}-\mathrm{NMR}$ (DMSO- $d_{6}$ ) analysis indicated that it was of sufficient purity to be used in the following step.

${ }^{1} \mathrm{H}-\mathrm{NMR}\left(300 \mathrm{MHz}\right.$ DMSO- $d_{6}$, room temperature) $\delta$ 'ppm=8.92 (d, 2H), 8.83 (s, 2H), 7.90 (d, 2H).

4,4'-dimethoxycarbonyl-2,2'-bipyridine (3)

4,4'-dicarboxy-2,2'-bipyridine $2(6.0 \mathrm{~g}, 27 \mathrm{mmol})$ in methanol $(100 \mathrm{~mL})$ was added into concentrated sulfuric acid $(12 \mathrm{~mL})$. After refluxing for $60 \mathrm{~h}$ the solution was poured into water $(250 \mathrm{~mL})$ forming a white slurry. The $\mathrm{pH}$ value of the slurry was adjusted to 8 with $25 \%$ (w/v) aqueous sodium hydroxide. The product was then extracted with chloroform, dried over sodium sulfate and evaporated to yield $6.7 \mathrm{~g}(27 \mathrm{mmol}, 99 \%)$ of product. ${ }^{1} \mathrm{H}-\mathrm{NMR}\left(\mathrm{CDCl}_{3}\right)$ analysis indicated that it was of sufficient purity to be used in the following step. ${ }^{1} \mathrm{H}-\mathrm{NMR} 300 \mathrm{MHz}\left(\mathrm{CDCl}_{3}, \mathrm{TMs}\right.$, room temperature $) \delta \mathrm{ppm}=$ $8.96(\mathrm{~s}, 2 \mathrm{H}), 8.86(\mathrm{~d}, 2 \mathrm{H}), 7.91(\mathrm{~d}, 2 \mathrm{H}), 4.00(\mathrm{~s}, 6 \mathrm{H})$.

4,4'-Bis(hydroxymethyl)-2,2'-bipyridine (4)

4,4'-dimethoxycarbonyl-2,2'-bipyridine $3(6.7 \mathrm{~g}, 27 \mathrm{mmol})$ dissolved in $500 \mathrm{ml}$ of anhydrous methanol (500 mL) was added sodium borohydride $(8.0 \mathrm{~g}, 211 \mathrm{mmol})$. After the reaction refluxed for 24 hours, it was cooled on the ice and then was added into another portion of sodium borohydride $(8.0 \mathrm{~g}, 211 \mathrm{mmol})$. The reaction mixture refluxed for 36 hours again. Then the reaction mixture was evaporated to dryness and enough water was added to dissolve the residue. The product was extracted with ethyl acetate, dried over sodium sulfate, and evaporated to dryness. Yield: $2.16 \mathrm{~g}$ (7.96 
mmol, 30\%). ${ }^{1} \mathrm{H}-\mathrm{NMR} 300 \mathrm{MHz}$ (DMSO-d 6 , TMs, room temperature) $\delta$ 'ppm = $8.60(\mathrm{~d}, 2 \mathrm{H}), 8.38(\mathrm{~s}, 2 \mathrm{H}), 7.36(\mathrm{~d}, 2 \mathrm{H})$, $5.50(\mathrm{~s}, 2 \mathrm{H}), 4.62(\mathrm{~d}, 4 \mathrm{H})$.

4,4'-Bis(bromomethyl)-2,2'-bipyridine (5)

4,4'-BisHydroxymethyl-2,2'-bipyridine 4 (2.5 g, $12 \mathrm{mmol})$ was dissolved in 49\% $\mathrm{HBr}$ solution (100 mL). After the reaction refluxed for $3.5 \mathrm{~h}$, it was cooled on the ice and then was neutralized with saturated sodium bicarbonate solution. Then the product was extracted with chloroform, dried over sodium sulfate, and evaporated to dryness. Yield: $1.2 \mathrm{~g}$ (3.5 mmol, 30\%). ${ }^{1} \mathrm{H}-\mathrm{NMR} 300 \mathrm{MHz}\left(\mathrm{CDCl}_{3}\right.$, TMs, room temperature) $\delta$ 'ppm = $8.68(\mathrm{~d}, 2 \mathrm{H}), 8.44(\mathrm{~s}, 2 \mathrm{H}), 7.39(\mathrm{~d}, 2 \mathrm{H})$, $4.64(\mathrm{~d}, 4 \mathrm{H})$.

4,4'-Bis\{2-[2-(2-triphenylmethoxyethoxy)ethoxy]ethoxymethyl\}-2,2'-bipyridine (6).

The compound 2-(2-Triphenylmethoxyethoxy)ethanol $(2.0 \mathrm{~g}, 5.7 \mathrm{mmol})$ dissolved in anhydrous THF $(100 \mathrm{~mL})$ and added to sodium hydride $(1.1 \mathrm{~g}, 28 \mathrm{mmol})$. After refluxing for $3 \mathrm{~h}$ under nitrogen, the reaction mixture was cooled to room temperature. Compound 4,4'-bis(bromomethyl)-2,2'-bipyridine 5 ( $0.60 \mathrm{~g}, 2.8 \mathrm{mmol})$ was added. The reaction was stirred at $30^{\circ} \mathrm{C}$ under nitrogen for 2 days, and TLC analysis indicated the starting material 4,4'-bis(bromomethyl)-2,2'-bipyridine disappeared. The reaction was quenched with methanol and evaporated to dryness. The residue was used directly in next step. 4,4'-Bis\{2-[2-(2-hydroxyethoxy)ethoxy]ethoxymethyl\}-2,2'-bipyridine (7). 
The residue of 6 was suspended in dichloromethane $(50 \mathrm{~mL})$, and was added into trifluoroacetic acid $(2.5 \mathrm{~mL})$. The solution was stirred at room temperature for $1 \mathrm{~h}$ and then washed with saturated ammonium bicarbonate. The mixture was purified on alumina (neutral) using a gradient of methanol in chloroform. Yield: $190 \mathrm{mg}(0.60 \mathrm{mmol}, 44 \%)$. ${ }^{1} \mathrm{H}-\mathrm{NMR} 300 \mathrm{MHz}\left(\mathrm{CDCl}_{3}\right.$, TMs, room temperature) $\delta$ 'ppm = $8.65(\mathrm{~d}, 2 \mathrm{H}), 8.41(\mathrm{~s}, 2 \mathrm{H}), 7.33(\mathrm{~d}, 2 \mathrm{H}), 4.69(\mathrm{~s}, 4 \mathrm{H})$, $3.78-3.60(\mathrm{~m}, 16 \mathrm{H})$.

4-\{2-\{2-[2-(4,4'-dimethoxytriphenylmethoxy)ethoxy]ethoxy\}-ethoxymethyl $-44^{\prime}-\{2-[2-(2-h y d r o x y e t h o x y)$ ethoxy] ethoxymet hyl $>2,2$ '-bipyridine $(\mathbf{8})$.

Dimethoxytrityl chloride $(0.20 \mathrm{~g}, 0.60 \mathrm{mmol})$ in anhydrous pyridine $(20 \mathrm{~mL})$ was dropped into the solution of 7 $(0.30 \mathrm{~g}, 0.70 \mathrm{mmol})$ and a catalytic amount of 4-dimethylaminopyridine in anhydrous pyridine $(30 \mathrm{~mL})$. The reaction was allowed to stir overnight at room temperature and then quenched with methanol. The mixture was washed with saturated sodium bicarbonate and purified on alumina (neutral) with a methanol gradient in chloroform. Yield: $84 \mathrm{mg}(0.27$ mmol, 20\%). ${ }^{1} \mathrm{H}-\mathrm{NMR} 300 \mathrm{MHz}\left(\mathrm{CDCl}_{3}, \mathrm{TMs}\right.$, room temperature) $\delta$ 'ppm = $8.63(\mathrm{~d}, 1 \mathrm{H}), 8.62(\mathrm{~d}, 1 \mathrm{H}), 8.39(\mathrm{~s}, 1 \mathrm{H})$, $8.34(\mathrm{~s}, 1 \mathrm{H}), 7.47$ (m, 1H), $7.46(\mathrm{~m}, 1 \mathrm{H}), 7.37-7.18(\mathrm{~m}, 9 \mathrm{H}), 6.81(\mathrm{~d}, 4 \mathrm{H}), 4.70(\mathrm{~s}, 2 \mathrm{H}), 4.69(\mathrm{~s}, 2 \mathrm{H}), 3.77(\mathrm{~s}, 6 \mathrm{H})$, 3.80-3.63 (m, 14H), 3.24(t, 2H). 
4-\{2-[2-(4,4'-dimethoxytriphenylmethoxy)ethoxy]-ethoxymethyl\}-4'-\{2-[2-O-\{(2-cyanoethoxy)-N,N'-diisoproplaminopho

sphino]ethoxy) ethoxymethyl $\}$-2,2'-bipyridine $(\mathbf{9})$.

Compound 8 (310 mg, $0.45 \mathrm{mmol})$ was azeotroped with dry acetonitrile to remove the moisture and dried in a vacuum. The sticky oil was dissolved in dry acetonitrile $(4.5 \mathrm{~mL})$ 2-Cyanoethyl $N, N, N^{\prime}, N^{\prime}$-tetraiso-propylphosphorodiamidite $(170 \mathrm{mg}, 0.56 \mathrm{mmol})$ was added to the solution with stirring. $1 H$-tetrazole (18 mg, $0.22 \mathrm{mmol}$ ) was then added, and the mixture was stirred at room temperature for 3 hours. The acetonitrile solution was sucked out using a syringe equipped a Whatman filter paper. The solution was directly used for the next DNA synthesis without further purification. 


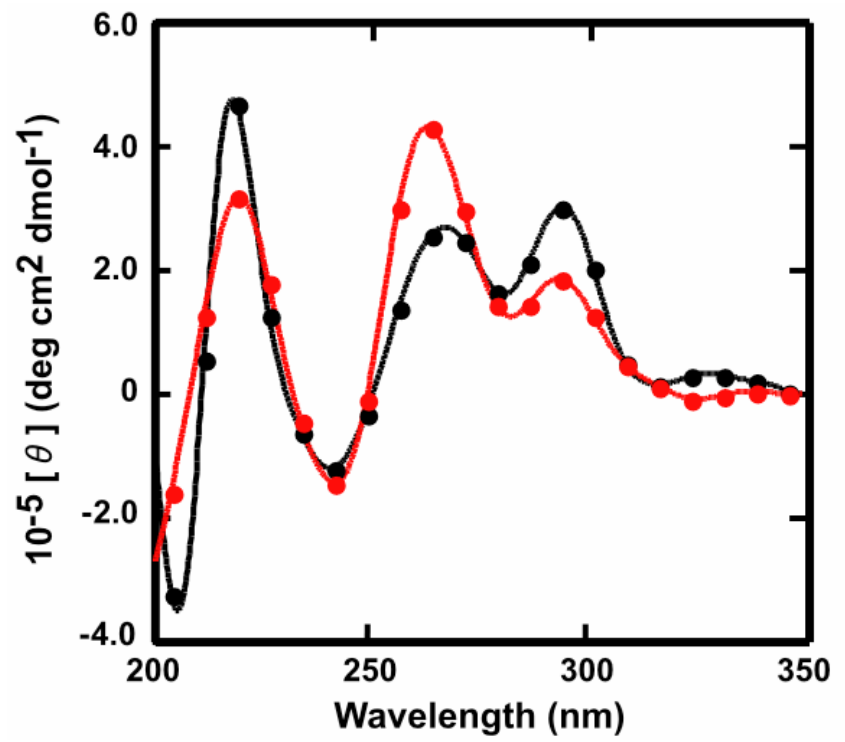

Figure S1. CD spectra for $5 \mu \mathrm{M} \mathrm{G} 1$ in buffer containing $100 \mathrm{mM} \mathrm{KCl}$ and $50 \mathrm{mM}$ MES (pH 6.0) in the absence (black), and presence of $2.5 \mu \mathrm{M} \mathrm{NiCl}_{2}$ (red) at $4{ }^{\circ} \mathrm{C}$. 


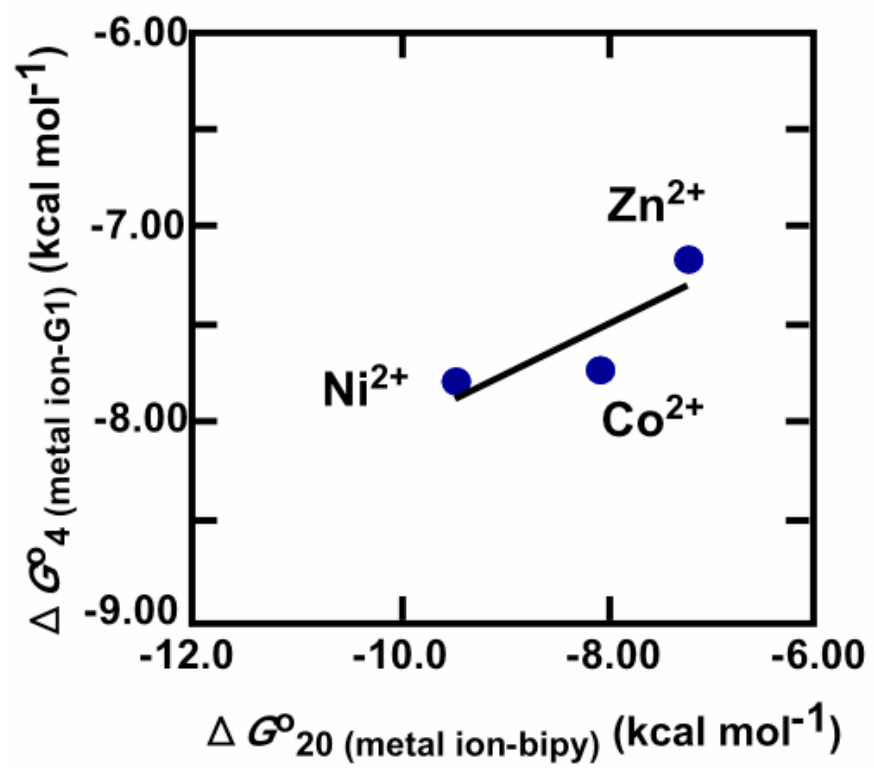

Figure S2. Relationship between the free energy change of formation of the divalent metal ion-G1 complex at $4{ }^{\circ} \mathrm{C}$ and the free energy change of the formation of the divalent metal ion-bipy complex at $20^{\circ} \mathrm{C}$. Metal ions used here are $\mathrm{Ni}^{2+}, \mathrm{Co}^{2+}$, and $\mathrm{Zn}^{2+}$. 


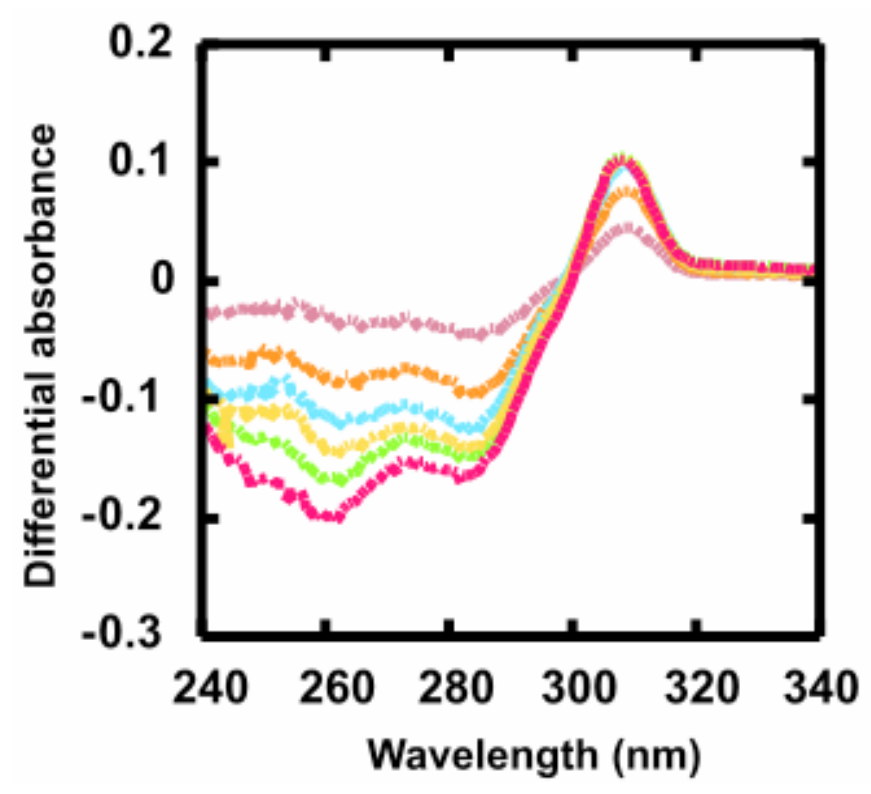

Figure S3. Differential UV spectra for $20 \mu \mathrm{M}$ G1 in buffer containing $100 \mathrm{mM}$ $\mathrm{NaCl}, 50 \mathrm{mM} \mathrm{MES}$ (pH 6.0), and $2 \mu \mathrm{M}$ (pink), $4 \mu \mathrm{M}$ (orange), $6 \mu \mathrm{M}$ (light blue), 10 $\mu \mathrm{M}$ (yellow), $20 \mu \mathrm{M}$ (light green), or $50 \mu \mathrm{M}$ (red) $\mathrm{NiCl}_{2}$ at $4{ }^{\circ} \mathrm{C}$. The differential spectra were obtained by subtraction of the UV spectra for solutions in the absence of $\mathrm{Ni}^{2+}$ from spectra obtained in the presence of $\mathrm{Ni}^{2+}$. 


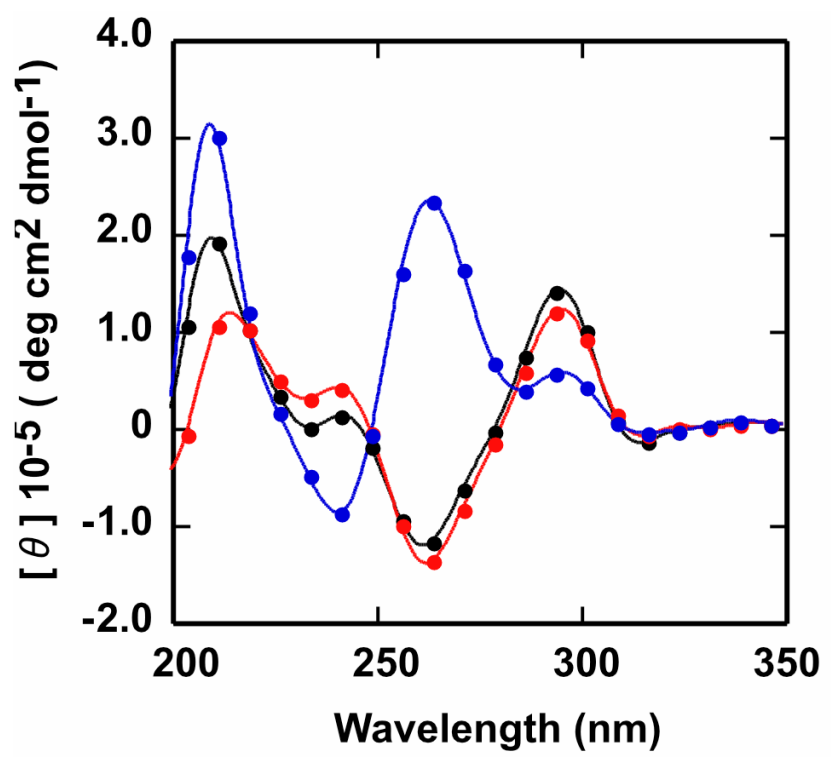

Figure S4. CD spectra for $20 \mu \mathrm{M} \mathrm{G} 1$ in buffer containing $100 \mathrm{mM} \mathrm{NaCl}$ and 50 $\mathrm{mM} \operatorname{MES}(\mathrm{pH}$ 6.0) (black), or $100 \mathrm{mM} \mathrm{NaCl}, 50 \mathrm{mM}$ MES (pH 6.0), and $10 \mu \mathrm{M}$ $\mathrm{NiCl}_{2}$ before (blue) and after chelation with Chelex (red) at $4^{\circ} \mathrm{C}$. 


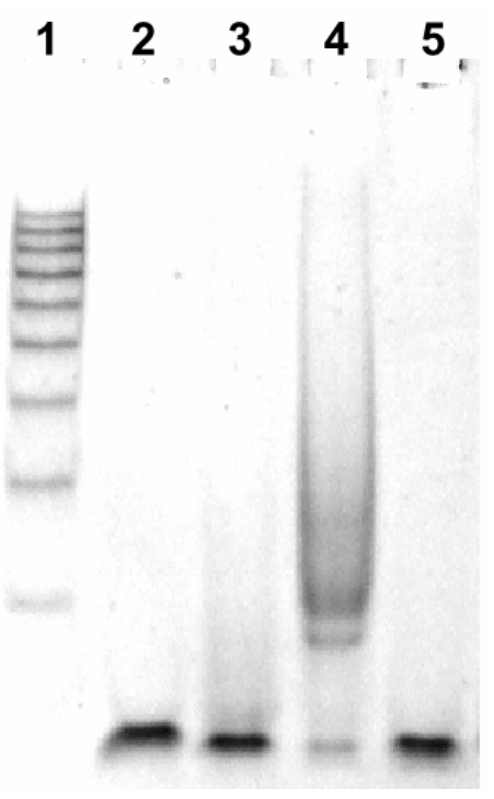

Figure S5. Native PAGE of $5 \mu \mathrm{M} \mathrm{G} 1$ in buffer containing $100 \mathrm{mM} \mathrm{NaCl}_{\mathrm{s}}$ and 50 mM MES ( $\mathrm{pH}$ 6.0) in the absence of $\mathrm{Ni}^{2+}$ (lane 3), or in the presence of $\mathrm{Ni}^{2+}, 100$ $\mu \mathrm{M} \mathrm{NiCl}_{2}$ ) (lane 4), or $100 \mu \mathrm{M} \mathrm{NiCl}_{2}$ and $120 \mu \mathrm{M} \mathrm{Na}_{2}$ EDTA (lane 5) at $4^{\circ} \mathrm{C}$. Lane 1: 10-base pair DNA ladder. Lane 2: $5 \mu \mathrm{M}$ G2 as a marker for the antiparallel G-quadruplex. 


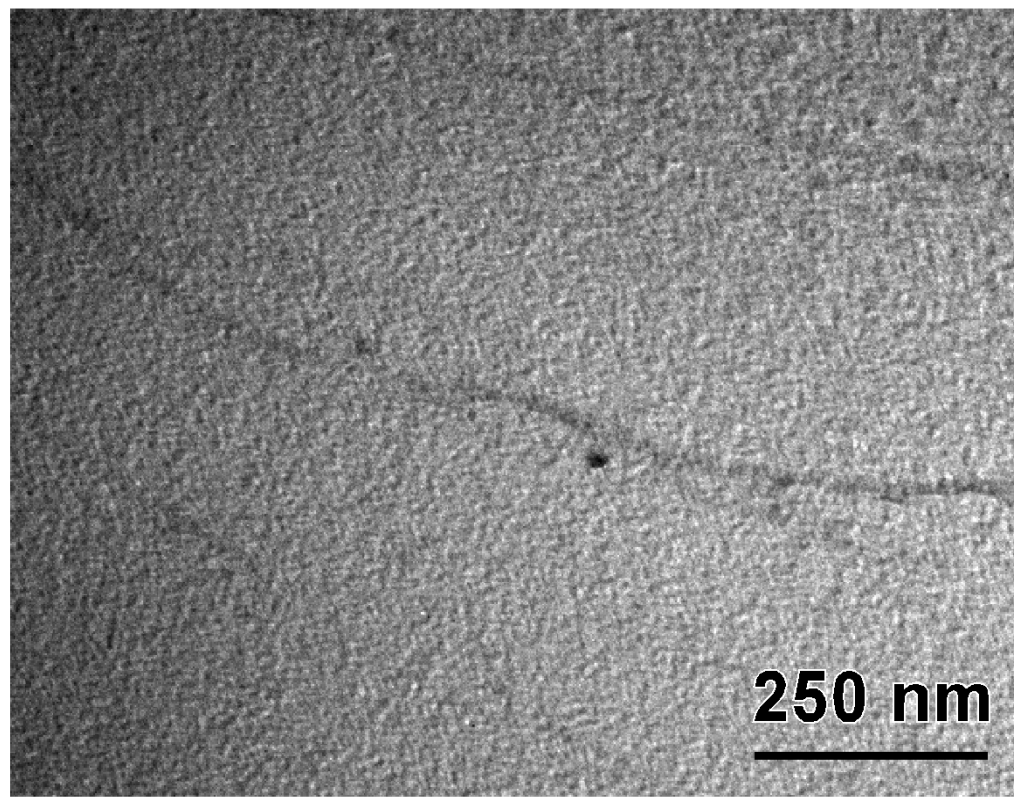

Figure S6. Transmission electron micrograph of G1 in buffer containing $100 \mathrm{mM}$ $\mathrm{NaCl}, 50 \mathrm{mM}$ MES (pH 6.0) and $10 \mu \mathrm{M} \mathrm{NiCl}_{2}$. The scale bar is $250 \mathrm{~nm}$. 
(a)

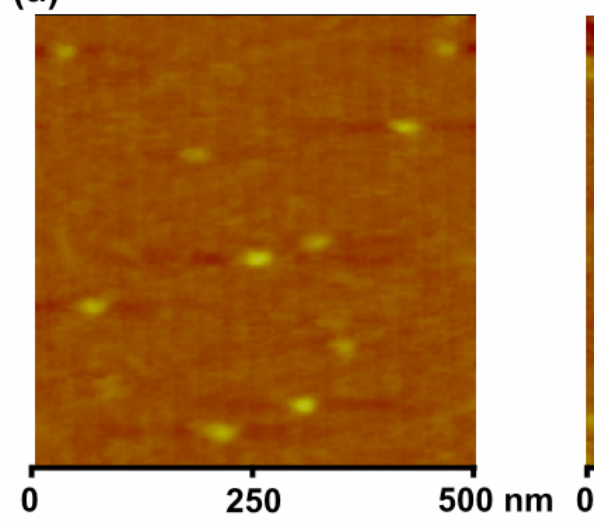

(b)

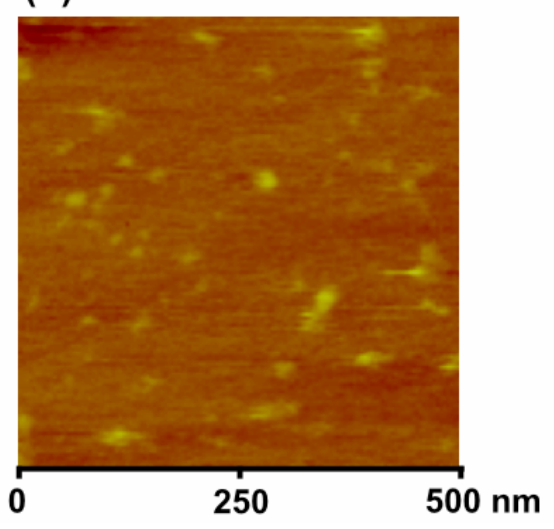

Figure S7. AFM images of G1 in buffers containing $100 \mathrm{mM} \mathrm{NaCl}$ and $50 \mathrm{mM}$ MES (pH 6.0) (a) and $50 \mu \mathrm{M} \mathrm{CoCl}_{2}$, or $100 \mathrm{mM} \mathrm{NaCl}$ and $50 \mathrm{mM} \mathrm{MES}(\mathrm{pH} \mathrm{6.0)}$ and $50 \mu \mathrm{M} \mathrm{ZnCl}_{2}(\mathrm{~b})$. 
(a)

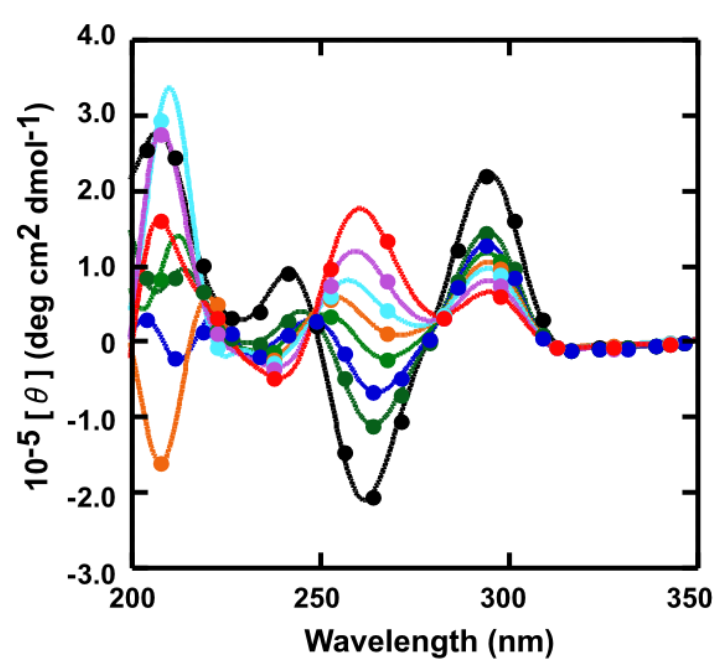

(b)

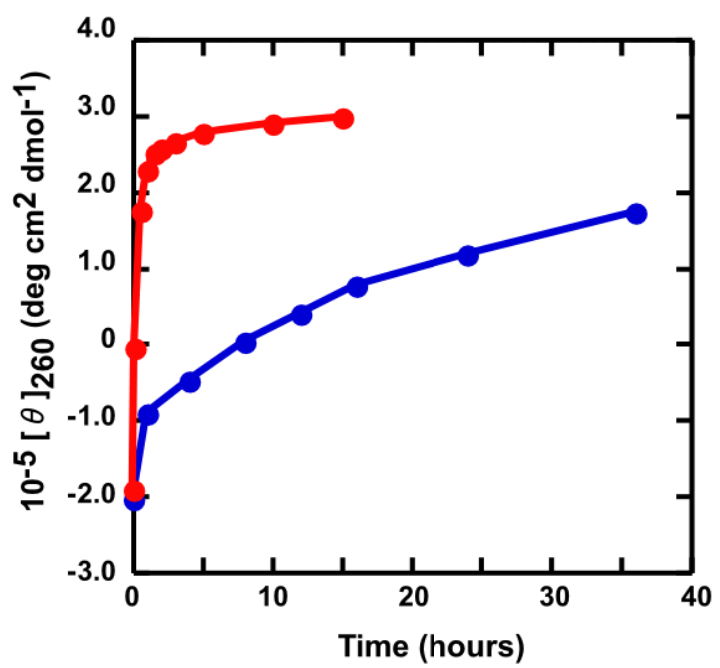

Figure S8. (a) CD spectra for $5 \mu \mathrm{M} \mathrm{G1}$ at $4{ }^{\circ} \mathrm{C}$ in buffer containing $100 \mathrm{mM}$ $\mathrm{NaCl}$ and $50 \mathrm{mM}$ MES ( $\mathrm{pH} 6.0$ ), and $100 \mu \mathrm{M} \mathrm{NiCl} \mathrm{N}_{2}$ with various periods of reaction time from 0 to 36 hours (from the bottom to the top at $260 \mathrm{~nm}$ ). (b) Time course of CD intensity change at $260 \mathrm{~nm}$ at $4{ }^{\circ} \mathrm{C}$ (blue) and at $25^{\circ} \mathrm{C}$ (red). 